19. Gao A-G, Lindberg FP, Finn MB, Blystone SD, Brown EJ, Frazier WA. Integrin-associated protein is a receptor for the C-terminal domain of thrombospondin. J Biol Chem 1996;271:21-24.

20. Dorahy DJ, Thorne RF, Fecondo JV, Burns GF. Stimulation of platelet activation and aggregation by a carboxyl-terminal peptide from thrombospondin binding to the integrin-associated protein receptor. J Biol Chem 1997;272:1323-1330.

21. Gao AG, Lindberg FP, Dimitry JM, Brown EJ, Frazier WA. Thrombospondin modulates $\alpha_{\mathrm{v} \beta 3}$ function through integrin-associated protein. J Cell Biol 1996;135:533-544.

22. Chung J, Gao A-G, Frazier WA. Thrombospondin acts via integrin-associated protein to activate the platelet integrin $\alpha_{\operatorname{IIb} \beta 3}$. J Biol Chem 1997;272:14740-14746.

23. Wang XQ, Lindberg FP, Frazier WA. Integrin-associated protein stimulates $\alpha_{2 \beta 1}$-dependent chemotaxis via Gi-mediated inhibition of adenylate cyclase and extracellular-regulated kinases. J Cell Biol 1999;147:389-400.

24. Santoro SA, Frazier WA. Isolation and characterization of thrombospondin. Methods Enzymol 1987;144:438-446.

25. Ruef J, Hu ZY, Yin LY, Wu Y, Hanson SR, Kelly AB, Harker LA, Rao GN, Runge MS, Patterson C. Induction of vascular endothelial growth factor in balloon-injured baboon arteries. A novel role for reactive oxygen species in atherosclerosis. Circ Res 1997;81:24-33.

26. Ticchioni M, Deckert M, Mary F, Bernard G, Brown EJ, Bernard A. Integrin-associated protein (CD47) is a comitogenic molecule on CD3-activated human T cells. J Immunol 1997;158:677-684.

27. Gao AG, Frazier WA. Identification of a receptor candidate for the carboxyl-terminal cell binding domain of thrombospondins. J Biol Chem 1994;269:29650-29657.
28. Schultz-Cherry S, Murphy-Ullrich JE. Thrombospondin causes activation of latent transforming growth factor- $\beta$ secreted by endothelial cells by a novel mechanism. J Cell Biol 1993;122:923-932.

29. Nam TJ, Busby WHJ, Rees C, Clemmons DR. Thrombospondin and osteopontin bind to insulin-like growth factor (IGF)-binding protein-5 leading to an alteration in IGF-I-stimulated cell growth. Endocrinology 2000;141:1100-1106.

30. Hogg PJ, Hotchkiss KA, Jimenez BM, Stathakis P, Chesterman $\mathrm{CN}$. Interaction of platelet-derived growth factor with thrombospondin 1 [published erratum appears in Biochem J 1999;341(pt 3):861]. Biochem J 1997;326:709-716

31. Chen D, Guo K, Yang J, Frazier WA, Isner JM, Andres V. Vascular smooth muscle cell growth arrest on blockade of thrombospondin-1 requires p21(Cip1/WAF1). Am J Physiol 1999;277: H1100-H1106.

32. Sajid M, Hu Z, Lele M, Stouffer GA. Protein complexes involving $\alpha_{\mathrm{v} \beta 3}$ integrins, nonmuscle myosin heavy chain-A and focal adhesion kinase form in thrombospondin-treated smooth muscle cells. J Investig Med 2000;48:190-197.

33. Guo K, Wolf V, Dharmarajan AM, Feng Z, Bielke W, Saurer, Friis R. Apoptosis-associated gene expression in the corpus luteum of the rat. Biol Reprod 1998;58:739-746.

34. Lindberg FP, Bullard DC, Caver TE, Gresham HD, Beaudet AL, Brown EJ. Decreased resistance to bacterial infection and granulocyte defects in IAP-deficient mice. Science 1996;274:795-798.

35. Oldenborg P, Zheleznyak A, Fang Y, Lagenaur CF, Gresham HD, Lindberg FP. Role of CD47 as a marker of self on red blood cells. Science 2000;288:2051-2054.

\title{
NOTICE OF WITHDRAWAL
}

V.R. Pante, A. Ali, J.E. Morley, and H.M. Perry III have withdrawn their abstract no. 147 "Effect of solid compared to liquid food intake in older persons," which appeared on page 259A in the September 2000 issue of the Journal, volume 48, issue 5. This is at the behest of the Institutional Review Board at the St Louis VA Medical Center. 